\title{
PENDAPATAN DAN FAKTOR-FAKTOR YANG MEMPENGARUHI PRODUKSI UBI KAYU MANIS DAN UBI KAYU PAHIT DI KECAMATAN SEPUTIH BANYAK KABUPATEN LAMPUNG TENGAH
}

\author{
(Income and Factors that Affecting the Production of Sweet Cassava and Bitter Cassava \\ in Seputih Banyak Central Lampung)
}

Jessica Anggraesi, Raden Hanung Ismono, Suriaty Situmorang

\begin{abstract}
Program Studi Agribisnis, Fakultas Pertanian, Universitas Lampung, Jl. Prof. Dr. Soemantri Brodjonegoro No.1 Bandar Lampung 35141, e-mail: hismono@fp.unila.ac.id
\end{abstract}

\begin{abstract}
The objectives of this study are to analyze factors affecting production, analyze the percentage of cassava farming income contribution to household income, and analyze the differences income of sweet cassava and bitter cassava farming. This research was conducted in March to April 2018 in Seputih Banyak, Central Lampung. The to determine production factors, the study used Cobb-Douglas production function. To determine contribution of cassava farming income to household income, the study used production analysis, while to determine income of sweet cassava and bitter cassava farming, the study used Independent Sample T-Test. The number of sample for bitter and sweet cassava were 30 respondents each chosen by nonproportional random sampling. The study indicates that the factors affecting production of bitter cassava are NPK fertilizer, urea fertilizer, SP-36 fertilizer, and harvest age, while the factors that significantly influence sweet cassava are land area and NPK fertilizer. The contribution of industrial cassava farming income to household income is $75.01 \%$, while sweet cassava income only accounts for $6.95 \%$ of total household income. There is a significant difference between the income of sweet cassava farming and bitter cassava farming.
\end{abstract}

Key words: cassava, income, production

\section{PENDAHULUAN}

Ubi kayu merupakan komoditas pangan yang dapat dijadikan sebagai sumber karbohidrat, dan melalui diversifikasi konsumsi dapat dimanfaatkan sebagai substitusi atau pengganti pangan pokok beras. Ubi kayu merupakan komoditas tanaman pangan di Indonesia yang menempati urutan ketiga setelah padi dan jagung.

Ubi kayu diklasifikasikan menjadi dua, yaitu ubi kayu manis dan ubi kayu pahit. Ubi kayu manis adalah ubi kayu yang biasa dikonsumsi langsung oleh masyarakat, sedangkan ubi kayu pahit digunakan sebagai bahan baku industri/ agroindustri. Budidaya ubi kayu manis dalam area yang luas sudah jarang ditemukan, kebanyakan hanya sebagai tanaman di pekarangan atau usaha sampingan. Petani mulai beralih menanam ubi kayu pahit yang memiliki pasar yang lebih besar, yaitu industri/agroindustri (Winarno 2002).

Luas panen ubi kayu di Kabupaten Lampung Tengah mencapai 60.716 ha dan produksi sebesar 157.217 ton membuat Kabupaten Lampung Tengah unggul dibandingkan dengan kabupaten lain yang ada di Provinsi Lampung, sehingga Kabupaten Lampung Tengah dikenal sebagai sentra produksi ubi kayu di Provinsi Lampung. Hampir seluruh daerah di Lampung Tengah menghasilkan ubi kayu, meskipun dengan luas panen dan produksi yang berbeda. Kecamatan Seputih Banyak merupakan penghasil ubi kayu cukup besar, yaitu urutan ke-9 dari 27 kecamatan di Lampung Tengah (BPS Kabupaten Lampung Tengah 2018).

Menurut Kepala Penyuluh Pertanian Seputih Banyak, hingga Januari 2018 hanya sekitar 10\% petani ubi kayu di Seputih Banyak yang membudidayakan ubi kayu manis dan 90\% membudidayakan ubi kayu pahit sebagai bahan baku industri. Minat petani untuk menanam ubi kayu manis terus berkurang, terkait dengan sulitnya menjual ubi kayu manis dalam jumlah yang besar, petani lebih memilih membudidayakan ubi kayu pahit. Sebaran produksi ubi kayu di Kecamatan Seputih Banyak dapat dilihat pada Gambar 1. 


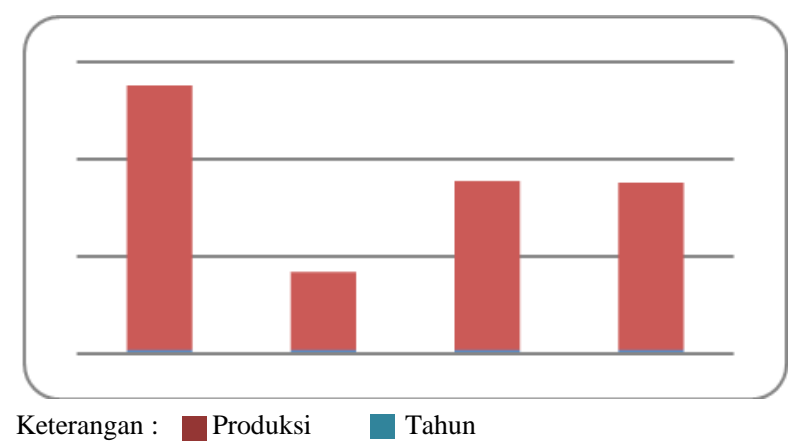

Gambar 1. Sebaran produksi ubi kayu di Kecamatan Seputih Banyak, 20132016

Produksi yang fluktuatif dan cenderung turun ini disebabkan oleh ketersedian input produksi yang masih belum terpenuhi dan harga ubi kayu yang masih rendah. Harga ubi kayu manis diperoleh dari kesepakatan antara penjual dan pembeli dengan proses tawar menawar. Konsumen ubi kayu manis biasanya adalah rumah tangga untuk keperluan konsumsi atau pedagang eceran di pasar. Umumnya petani ubi kayu panen dalam waktu 6 atau 7 bulan, sehingga pabrik menentukan potongan sebesar $17-24 \%$ dari harga yang diterima petani sesuai dengan kandungan pati masingmasing ubi kayu. Hal tersebut tentu sangat berpengaruh terhadap pendapatan petani. Sebesar $72,5 \%$ petani ubi kayu manis dan $43,3 \%$ petani ubi kayu pahit memiliki usahatani lain selain ubi kayu, yaitu usahatani jagung. Sebesar 30\% petani ubi kayu pahit dan 53,3\% petani ubi kayu manis memiliki pekerjaan sampingan seperti buruh dan dagang.

Berdasarkan uraian tersebut, maka tujuan penelitian ini adalah menganalisis faktor-faktor yang mempengaruhi produksi, menganalisis persentase sumbangan pendapatan usahatani terhadap pendapatan rumah tangga, dan menganalisis perbedaan pendapatan antara ubi kayu pahit dan ubi kayu manis di Kecamatan Seputih Banyak Kabupaten Lampung Tengah.

\section{METODE PENELITIAN}

Penelitian ini dilakukan dengan metode survey di Desa Sakti Buana dan Sanggar Buana, Kecamatan Seputih Banyak, Kabupaten Lampung Tengah. Lokasi ini dipilih secara sengaja dengan pertimbangan bahwa Desa Sakti Buana dan Sanggar Buana memiliki lahan kering yang luas dibandingkan desa lainnya dan belum pernah dijadikan tempat penelitian sebelumnya.
Jumlah petani ubi kayu pahit di Kecamatan Seputih Banyak adalah 1.220 petani dan petani ubi kayu manis 231 petani. Metode pengambilan sampel yang digunakan adalah Non-proportional Random Sampling berdasarkan kelompok (Arikunto 2006), dimana untuk setiap kelompok ubi kayu manis dan ubi kayu pahit diambil jumlah sampel yang sama. Jumlah responden ubi kayu pahit 30 orang, dan responden ubi kayu manis 30 orang (Sekaran 2013). Data yang diperlukan dalam penelitian ini adalah data primer dan sekunder. Data primer diperoleh dengan wawancara langsung dengan responden menggunakan kuisioner, sedangkan data sekunder diperoleh dari literatur, instansi (lembaga) dan penelitian terdahulu yang terkait dengan penelitian.

Metode analisis data yang digunakan adalah analisis deskriptif kuantitatif dan metode statistik. Faktor-faktor yang mempengaruhi produksi ubi kayu pahit dan ubi kayu manis dianalisis dengan menggunakan fungsi produksi Cobb-Douglas sejalan dengan penelitian (Sinabariba 2014). Fungsi produksi Cobb-Douglas adalah suatu fungsi produksi yang ingin memperlihatkan pengaruh input yang digunakan dengan output yang diinginkan. Fungsi ini merupakan fungsi produksi yang secara luas digunakan untuk mewakili hubungan input dan output. Fungsi produksi Cobb-Douglas ditulis sebagai (Soekartawi 2003):

$\mathrm{Y}=\mathrm{bo} \mathrm{X}_{1}^{\mathrm{b} 1} \mathrm{X}_{2}{ }^{\mathrm{b} 2} \mathrm{X}_{3}{ }^{\mathrm{b} 3} \mathrm{X}_{4}{ }^{\mathrm{b} 4} \mathrm{X}_{5}{ }_{6}^{\mathrm{b} \mathrm{X}}{ }_{6}^{\mathrm{b} 6} \mathrm{X}_{7}{ }^{\mathrm{b} 7} \mathrm{X}_{8}{ }^{\mathrm{b} 8} \mathrm{D}^{\mathrm{ed}+\mathrm{u}}$

Keterangan:

$Y \quad=$ Produksi ubi kayu $(\mathrm{kg})$

bo $\quad=$ Intersep

$b 1 . . b 7=$ Koefisien regresi $X$

$d \quad=$ Koefisien regresi $D$

$\mathrm{X}_{1} \quad=$ Luas lahan (ha)

$\mathrm{X}_{2} \quad=$ Jumlah bibit (batang)

$\mathrm{X}_{3} \quad=$ Pupuk NPK Phonska $(\mathrm{kg})$

$\mathrm{X}_{4} \quad=$ Pupuk urea $(\mathrm{kg})$

$\mathrm{X}_{5} \quad=$ Pupuk SP36 $(\mathrm{kg})$

$\mathrm{X}_{6} \quad=$ Pupuk kandang $(\mathrm{kg})$

$\mathrm{X}_{7}=$ Tenaga kerja (HOK)

$\mathrm{X}_{8}=$ Umur panen (bulan)

$\mathrm{D}=$ Musim panen $(1=$ musim hujan, $0=$ musim kemarau)

$e \quad=$ Bilangan natural $(2,718)$

Persamaan yang dianalisis harus melalui uji asumsi klasik multikolinieritas dan heteroskedastisitas. Uji multikolinieritas dilakukan untuk mengetahui apakah terdapat korelasi atau hubungan antar variabel bebas (Soekartawi 2003). Jika variabelvariabel bebas saling berkorelasi (koefisien 
korelasinya di atas 0,8 ) dan nilai $R^{2}$ sebagai ukuran goodness of fit yang dihasilkan oleh estimasi model regresi tinggi, dan nilai toleransi $<0,10$ atau sama dengan nilai VIF (Variance Inflation Factor) $>10$, maka mengindikasikan adanya multikolinieritas. Heteroskedastisitas terjadi apabila kesalahan atau residual dari model yang diamati tidak memiliki varians yang konstan dari satu observasi ke observasi lain. Gejala heteroskedastis dapat diketahui dengan melakukan Uji White.

Analisis pendapatan digunakan untuk melihat seberapa besar pendapatan yang diperoleh dari usahatani ubi kayu pahit maupun ubi kayu manis tersebut dan layak atau tidak untuk diusahakan berdasarkan nilai R/C. Analisis pendapatan usahatani secara matematis dapat dirumuskan sebagai berikut:

$\begin{array}{ll}\pi & =Y . P y-\Sigma X i . P x i \\ \text { R/C } & =Y . P y / \Sigma X i . P X i\end{array}$

Keterangan:

$$
\begin{array}{ll}
\pi & =\text { Pendapatan }(\mathrm{Rp}) \\
\mathrm{R} / \mathrm{C} & =\text { Nisbah penerimaan }(\mathrm{R}) \text { dan biaya }(\mathrm{C}) \\
\mathrm{Y} & =\text { Produksi ubi kayu }(\mathrm{Kg}) \\
\mathrm{Py} & =\text { Harga ubi kayu }(\mathrm{Rp}) \\
\mathrm{Xi} & =\text { Faktor produksi }(\mathrm{i}=1,2,3, \ldots \ldots, \mathrm{n}) \\
\mathrm{Pxi} & =\text { Harga faktor produksi ke-i }(\mathrm{Rp})
\end{array}
$$

Kriteria pengambilan keputusan adalah (Soekartawi 2002):

a. Jika R/C > 1, maka usahatani mengalami keuntungan, karena penerimaan lebih besar dari biaya.

b. Jika $\mathrm{R} / \mathrm{C}<1$, maka usahatani mengalami kerugian, karena penerimaan lebih kecil dari biaya.

c. Jika $\mathrm{R} / \mathrm{C}=1$, maka usahatani dalam keadaan impas, karena penerimaan sama dengan biaya.

Pendapatan rumah tangga petani ubi kayu manis dan ubi kayu pahit diperoleh dengan menjumlahkan pendapatan usahatani ubi kayu, pendapatan usahatani non ubi kayu, dan pendapatan non usahatani atau di luar usahatani. Analisis statistik uji beda rata-rata atau t-hitung (independent sample t-test) dengan uji dua arah digunakan untuk membandingkan rata-rata pendapatan usahatani ubi kayu.

Pengambilan keputusan dalam analisis uji t dapat dilakukan dengan dua cara, yaitu berdasarkan perbandingan t-hitung dan t-tabel dan berdasarkan perbandingan nilai probabilitas atau nilai signifikansi, dengan kriteria uji (Sumodiningrat dan Iswara 1993):

(1) Jika t-hitung $\leq \mathrm{t}$-tabel, maka Ho diterima dan $\mathrm{H}_{1}$ tidak diterima, artinya tidak terdapat perbedaan pendapatan usahatani ubi kayu pahit dan ubi kayu manis.

(2) Jika t-hitung > t-tabel, maka Ho ditolak dan $\mathrm{H}_{1}$ diterima, artinya terdapat perbedaan pendapatan usahatani ubi kayu pahit dan ubi kayu manis.

\section{HASIL DAN PEMBAHASAN}

\section{Keadaan Umum Responden}

Umur responden petani ubi kayu pahit dan ubi kayu manis adalah di atas 35 tahun, dengan tingkat pendidikan Sekolah Dasar dan Sekolah Menengah Pertama. Jumlah anggota keluarga petani ubi kayu pahit maupun petani ubi kayu manis adalah 4-5 orang. Pengalaman berusahatani petani ubi kayu pahit rata-rata 20 tahun dengan persentase sebesar $50 \%$, sedangkan pengalaman berusahatani petani ubi kayu manis adalah 8-16 tahun dan 17-25 tahun masing-masing sebesar $40 \%$. Sebesar $70 \%$ petani ubi kayu pahit dan $53,33 \%$ petani ubi kayu manis memiliki pekerjaan sampingan di luar usahatani. Pekerjaan sampingan yang dilakukan adalah buruh pabrik dan dagang. Rata-rata luas lahan petani ubi kayu pahit adalah 2,3 ha, sedangkan rata-rata luas lahan petani ubi kayu manis adalah 0,024 ha.

\section{Faktor-faktor yang Mempengaruhi Produksi Ubi Kayu}

Faktor-faktor yang diduga berpengaruh terhadap produksi ubi kayu adalah luas lahan $\left(\mathrm{X}_{1}\right)$, bibit $\left(\mathrm{X}_{2}\right)$, pupuk NPK $\left(\mathrm{X}_{3}\right)$, pupuk urea $\left(\mathrm{X}_{4}\right)$, pupuk SP$36\left(\mathrm{X}_{5}\right)$, pupuk kandang $\left(\mathrm{X}_{6}\right)$, tenaga kerja $\left(\mathrm{X}_{7}\right)$, umur panen $\left(\mathrm{X}_{8}\right)$, dan musim panen (D). Persamaan (model) ubi kayu pahit tidak memiliki masalah penyimpangan asumsi klasik heteroskedastisitas, dilihat dari nilai Prob. $O b s^{*} R$ squared $\geq 0,05$ tetapi mengalami multikolinieritas, sehingga variabel yang berkorelasi tinggi dikeluarkan dari model, dan faktor-faktor yang diduga berpengaruh terhadap produksi ubi kayu pahit adalah luas lahan $\left(\mathrm{X}_{1}\right)$, bibit $\left(\mathrm{X}_{2}\right)$, pupuk NPK $\left(X_{3}\right)$, tenaga kerja $\left(X_{7}\right)$, dan musim panen (D). Hasil regresi dapat dilihat pada Tabel 1.

Persamaan fungsi produksi ubi kayu pahit adalah:

$$
\begin{aligned}
\mathrm{LnY}= & 8,640-0,010 \mathrm{LnX}_{1}-0,381 \mathrm{LnX}_{2}+0,223 \\
& \operatorname{LnX}_{3}+1,073 \mathrm{LnX}_{7}+0,084 \mathrm{D}, \text { atau: } \\
\mathrm{Y}= & 109,64 \mathrm{X}_{1}^{-0,01} \mathrm{X}_{2}^{-0,381} \mathrm{X}_{3}^{0,223} \mathrm{X}_{7}^{1,073} \mathrm{D}^{0,084}
\end{aligned}
$$


Tabel 1. Hasil analisis regresi ubi kayu pahit di Kecamatan Seputih Banyak Kabupaten Lampung Tengah, 2018

\begin{tabular}{lcccc}
\hline \multicolumn{1}{c}{ Model } & Koefisien & t-Statistik & Prob. & VIF \\
\hline Ln(Constant) & 8,640 & 8,420 & 0,000 & \\
LnX1 (luas lahan) & $-0,010$ & $-0,137$ & 0,892 & 4,311 \\
LnX2 (bibit) & $-0,381^{* * *}$ & $-3,477$ & 0,002 & 4,583 \\
LnX3 (pupuk NPK) & $0,223^{* * *}$ & 3,358 & 0,003 & 5,304 \\
LnX7 (tenaga kerja) & $1,073^{* * *}$ & 10,958 & 0,000 & 9,203 \\
D (musim panen) & $0,084^{* * *}$ & 2,996 & 0,006 & 1,416 \\
\hline R-squared & & & 0,981 & \\
Adjusted R-squared & & & 0,977 & \\
F-statistic & & & 0,000 & \\
Prob(F-statistic) & & & 0,659 & \\
Prob. Obs*R-squared & & &
\end{tabular}

Nilai Adjusted R-squared sebesar 0,977 (97,70\%). Artinya sebesar 97,70 persen variasi produksi ubi kayu pahit dapat dijelaskan oleh luas lahan $\left(X_{1}\right)$, bibit $\left(X_{2}\right)$, pupuk $\operatorname{NPK}\left(X_{3}\right)$, tenaga kerja $\left(X_{7}\right)$, dan musim panen $(D)$, sedangkan sisanya sebesar 2,30 persen dijelaskan oleh variabel lain yang tidak dimasukkan ke dalam model. Nilai Prob. Fstatistik sebesar 0,0001 artinya secara bersamasama variabel luas lahan $\left(X_{1}\right)$, bibit $\left(X_{2}\right)$, pupuk NPK $\left(X_{3}\right)$, tenaga kerja $\left(X_{7}\right)$, dan musim panen $(D)$ nyata berpengaruh terhadap produksi ubi kayu pahit dengan tingkat kepercayaan $99 \%$. Berdasarkan nilai t-statistik, secara individu faktorfaktor yang nyata berpengaruh terhadap produksi ubi kayu adalah bibit $\left(X_{2}\right)$ jika bibit ditambah sebesar $1 \%$ akan menurunkan produksi sebesar $0,381 \%$, pupuk NPK $\left(X_{3}\right)$ jika pupuk NPK ditambah sebesar $1 \%$ akan meningkatkan produksi sebesar $0,223 \%$, tenaga kerja $\left(X_{7}\right)$ jika tenaga kerja ditambah sebesar $1 \%$ akan meningkatkan produksi sebesar $1,073 \%$, dan musim panen (D) jika petani panen pada musim hujan, produksi akan meningkat sebesar $0,084 \%$.

Persamaan ubi kayu manis tidak memiliki masalah penyimpangan asumsi klasik heteroskedastisitas, dilihat dari nilai Prob. Obs*R-squared $\geq 0,05$ tetapi mengalami multikolinieritas, sehingga variabel yang berkoreladsi tinggi dikeluarkan dari model, dan faktor-faktor yang diduga berpengaruh terhadap produksi ubi kayu manis adalah luas lahan $\left(X_{1}\right)$, pupuk NPK $\left(X_{3}\right)$, pupuk Urea $\left(X_{4}\right)$, pupuk SP-36 $\left(X_{5}\right)$, tenaga kerja $\left(X_{7}\right)$, umur panen $\left(X_{8}\right)$, dan musim panen $(D)$. Hasil regresi ubi kayu manis dapat dilihat pada Tabel 2.

Persamaan fungsi produksi ubi kayu manis adalah :

$$
\begin{aligned}
\operatorname{LnY}= & 9,707+1,045 \operatorname{LnX}_{1}-0,226 \operatorname{LnX}_{3}+0,149 \\
& \operatorname{LnX}_{4}-0,143 \operatorname{LnX}_{5^{-}} 0,160 \operatorname{LnX}_{7}+0,736 \\
& \operatorname{LnX}_{8}-0,115 \mathrm{D}, \text { atau: } \\
\mathrm{Y}= & 141,30 \mathrm{X}_{1}^{1,045} \mathrm{X}_{3}^{-0,226} \mathrm{X}_{4}^{0,149} \mathrm{X}_{5}^{-0,143} \mathrm{X}_{7}^{-0,160} \\
& \mathrm{X}_{8}^{0,736} \mathrm{D}^{-0,115}
\end{aligned}
$$

Tabel 2. Hasil analisis regresi ubi kayu manis di Kecamatan Seputih Banyak Kabupaten Lampung Tengah, 2018

\begin{tabular}{lcccc}
\hline \multicolumn{1}{c}{ Model } & Koefisien & t-Statistik & Prob. & VIF \\
\hline Ln(Constant) & 9,707 & 6,171 & 0,000 & \\
LnX1 (luas lahan) & $1,045^{* * *}$ & 5,849 & 0,000 & 4,906 \\
LnX3 (pupuk NPK) & $-0,226^{*}$ & $-1,901$ & 0,071 & 2,038 \\
LnX4 (pupuk Urea) & 0,149 & 1,067 & 0,298 & 2,103 \\
LnX5 (pupuk SP-36) & $-0,143$ & $-1,375$ & 0,183 & 1,902 \\
LnX7 (tenaga kerja) & $-0,160$ & $-1,228$ & 0,232 & 2,123 \\
LnX8 (umur panen) & 0,736 & 1,575 & 0,129 & 1,175 \\
D (musim panen) & $-0,115$ & $-1,486$ & 0,152 & 1,347 \\
\hline R-squared & & & 0,821 & \\
Adjusted R-squared & & & 0,765 & \\
F-statistic & & & 0,000 & \\
Prob(F-statistic) & & & 0,053 & \\
Prob. Obs*R-squared & & & & \\
Keterangan:*** = Nyata pada taraf 99 persen ${ }^{* *}=$ Nyata pada taraf 95 persen $*$ = Nyata pada taraf 90 persen &
\end{tabular}


Nilai Adjusted $R$-square pada model persamaan ini adalah $0,765(76,50 \%)$, artinya setelah disesuaikan sebesar $76,50 \%$ variasi produksi ubi kayu manis dapat dijelaskan oleh variabel luas lahan $\left(X_{1}\right)$, pupuk NPK $\left(X_{3}\right)$, pupuk Urea $\left(X_{4}\right)$, pupuk SP-36 $\left(X_{5}\right)$, tenaga kerja $\left(X_{7}\right)$, umur panen $\left(X_{8}\right)$, dan musim panen $(D)$, sedangkan sisanya sebesar $23,50 \%$ dijelaskan oleh variabel lain yang tidak dimasukkan ke dalam model. Nilai signifikansi Fstatistik sebesar 0,000 artinya secara bersama-sama variabel luas lahan $\left(X_{1}\right)$, pupuk NPK $\left(X_{3}\right)$, pupuk Urea $\left(X_{4}\right)$, pupuk SP-36 $\left(X_{5}\right)$, tenaga kerja $\left(X_{7}\right)$, umur panen $\left(X_{8}\right)$, dan musim panen $(D)$ nyata berpengaruh terhadap produksi ubi kayu manis dengan tingkat kepercayaan sebesar $99 \%$.

Berdasarkan nilai t-statistik, secara individu faktorfaktor yang nyata berpengaruh terhadap produksi ubi kayu manis adalah luas lahan $\left(X_{1}\right)$ jika luas lahan ditambah $1 \%$ akan meningkatkan produksi sebesar $1,045 \%$, dan pupuk NPK $\left(X_{3}\right)$ jika pupuk NPK ditambah sebesar $1 \%$ akan menurunkan produksi sebesar $0,226 \%$. Anjuran penggunaan pupuk urea adalah $100-150 \mathrm{~kg} / \mathrm{ha}$, dan pupuk NPK $100 \mathrm{~kg} / \mathrm{ha}$ (BPTP Lampung 2008). Penggunaan pupuk NPK ubi kayu manis adalah $98,75 \mathrm{~kg} / \mathrm{ha}$, jika ditambah pupuk urea $211 \mathrm{~kg} / \mathrm{ha}$ yang memiliki kandungan unsur yang juga terdapat pada pupuk NPK, maka penggunaannya berlebih. Faktor produksi pupuk Urea $\left(X_{4}\right)$, pupuk SP-36 $\left(X_{5}\right)$, tenaga kerja $\left(X_{7}\right)$, umur panen $\left(X_{8}\right)$, dan musim panen (D) tidak nyata berpengaruh terhadap produksi ubi kayu manis.

\section{Pendapatan Usahatani Ubi Kayu Pahit}

Pendapatan usahatani ubi kayu merupakan selisih antara penerimaan dan biaya usahatani ubi kayu. Biaya total adalah seluruh biaya yang dikeluarkan oleh petani, terdiri atas biaya tunai dan biaya diperhitungkan. Biaya tunai adalah biaya yang dibayarkan secara tunai oleh petani, terdiri dari biaya bibit, pupuk, obat-obatan, tenaga kerja luar keluarga, pajak dan potongan harga oleh pabrik sebesar 17-24\% (sesuai dengan kandungan pati dalam ubi kayu). Biaya diperhitungkan adalah biaya yang dikeluarkan oleh petani, tetapi tidak dibayarkan secara tunai, terdiri dari sewa lahan milik sendiri, penyusutan peralatan dan bangunan milik sendiri, dan tenaga kerja dalam keluarga.

Tabel 3. Analisis usahatani ubi kayu pahit di Kecamatan Seputih Banyak Kabupaten Lampung Tengah, 2018

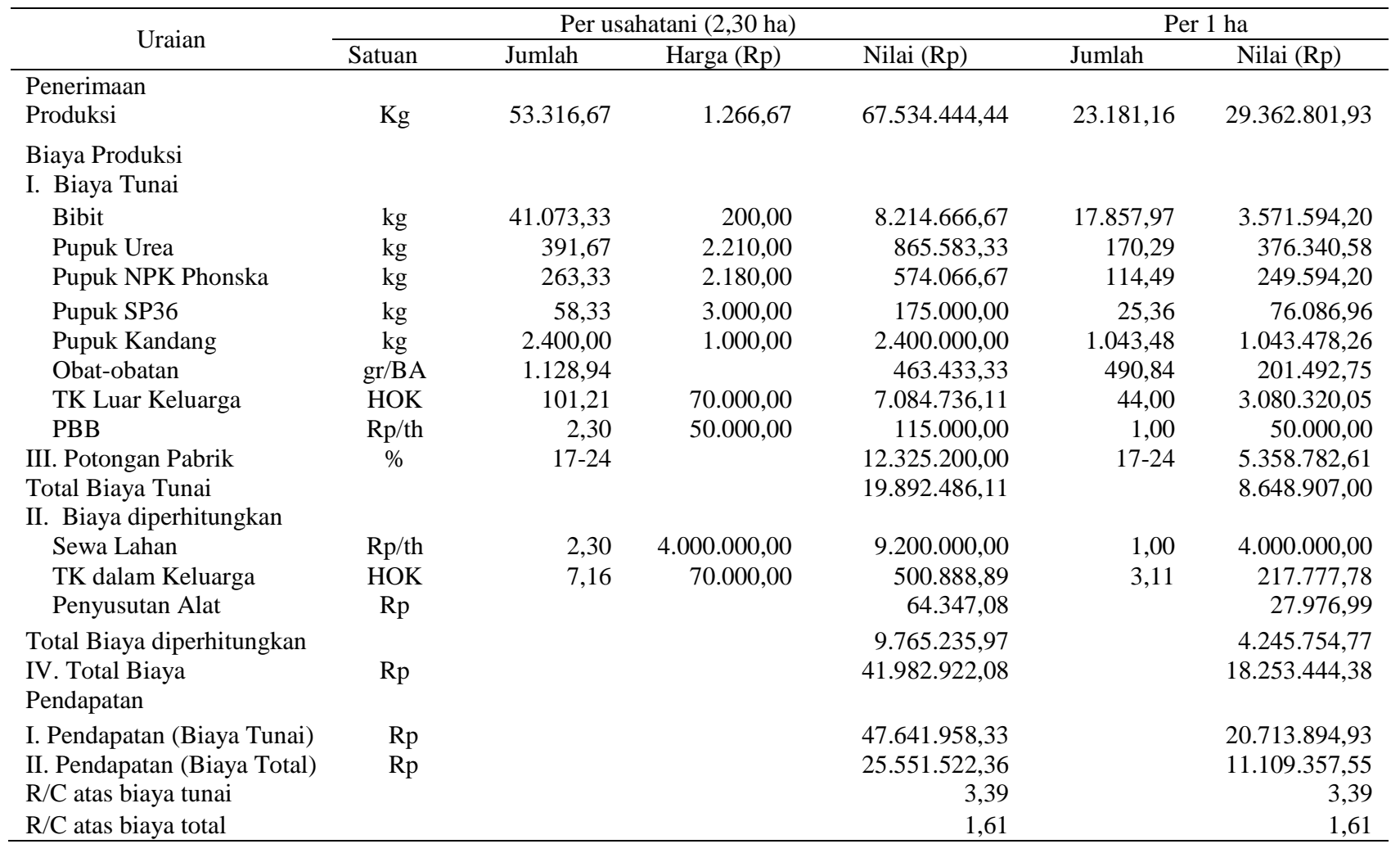

Analisis usahatani ubi kayu pahit di Kecamatan Seputih Banyak dapat dilihat pada Tabel 3. Nilai 
nisbah penerimaan dengan biaya $(\mathrm{R} / \mathrm{C})$ atas biaya tunai dan biaya total usahatani ubi kayu pahit lebih besar dari satu $(R / C>1)$. Nilai $R / C$ atas biaya tunai sebesar 3,39 artinya setiap Rp1 biaya yang dikeluarkan untuk usahatani ubi kayu pahit akan menghasilkan penerimaan sebesar Rp3,39. Nilai $\mathrm{R} / \mathrm{C}$ atas biaya total adalah 1,61 artinya setiap Rp1 biaya yang dikeluarkan untuk usahatani ubi kayu pahit akan menghasilkan penerimaan sebesar Rp1,61 artinya usahatani ubi kayu pahit layak untuk dijalankan sejalan dengan penelitian (Ambarita 2014).

\section{Pendapatan Usahatani Ubi Kayu Manis}

Pendapatan usahatani ubi kayu manis berbeda dengan pendapatan usahatani ubi kayu pahit, karena penerimaan usahatani ubi kayu manis tidak dikurangi biaya potongan pabrik. Pendapatan usahatani ubi kayu manis dapat dilihat pada Tabel 4. Pendapatan atas biaya total sebesar $\mathrm{Rp} 1.384 .055,83$ dengan nilai $\mathrm{R} / \mathrm{C}$ atas biaya tunai sebesar 13,03 dan nilai R/C atas biaya total sebesar 2,01 artinya setiap Rp1 biaya total untuk usahatani ubi kayu manis akan menghasilkan penerimaan sebesar Rp 2.01. Usahatani ubi kayu manis layak untuk dijalan apabila dilihat dari nilai $\mathrm{R} / \mathrm{C}$, tapi melihat kenyataan dilapangan terkait sulitnya pasar untuk menjual ubi kayu manis, petani lebih memilih menanam ubi kayu pahit yang memiliki permintaan besar. Ubi kayu manis hanya ditanam untuk keperluan konsumsi dan industri skala kecil seperti pembuatan tape singkong.

\section{Persentase Sumbangan Pendapatan Usahatani Ubi Kayu terhadap Pendapatan Rumah Tangga Petani Ubi Kayu Manis dan Ubi Kayu Pahit}

Semakin besar pendapatan usahatani akan semakin besar pula pendapatan rumah tangganya. Persentase sumbangan pendapatan usahatani terhadap pendapatan rumah tangga petani ubi disajikan pada Tabel 5. Pendapatan usahatani (ubi kayu dan nonubi kayu) lebih besar sumbangannya terhadap pendapatan rumah tangga, jika dibandingkan dengan pendapatan nonusahatani.

Pendapatan usahatani ubi kayu pahit memiliki pengaruh yang sangat besar terhadap pendapatan rumah tangga petani ubi kayu pahit, yaitu menyumbang sebesar $75,01 \%$ dari total pendapatan rumah tangga petani ubi kayu pahit, sedangkan usahatani ubi kayu manis hanya menyumbang sebesar $6,95 \%$ dari total pendapatan rumah tangga petani ubi kayu manis. Sebesar 63,91\% pendapatan rumah tangga petani ubi kayu manis berasal dari pendapatan usahatani lain.

Tabel 4. Analisis usahatani ubi kayu manis di Kecamatan Seputih Banyak Kabupaten Lampung Tengah, 2018

\begin{tabular}{|c|c|c|c|c|c|c|}
\hline \multirow{2}{*}{ Uraian } & \multicolumn{4}{|c|}{ Per usahatani $(0,024$ ha $)$} & \multicolumn{2}{|c|}{ Per 1 ha } \\
\hline & Satuan & Jumlah & Harga $(\mathrm{Rp})$ & Nilai (Rp) & Jumlah & Nilai (Rp) \\
\hline \multicolumn{7}{|l|}{ Penerimaan } \\
\hline Produksi & $\mathrm{kg}$ & $1.021,67$ & $2.700,00$ & $2.758 .500,00$ & $42.569,44$ & $114.937 .500,00$ \\
\hline \multicolumn{7}{|l|}{ Biaya Produksi } \\
\hline \multicolumn{7}{|l|}{ I. Biaya Tunai } \\
\hline Bibit & $\mathrm{kg}$ & 400,00 & 250,00 & $100.000,00$ & $16.666,67$ & 4.166.666,67 \\
\hline Pupuk Urea & $\mathrm{kg}$ & 5,07 & $2.180,00$ & $11,045.33$ & 211,11 & $460.222,22$ \\
\hline Pupuk NPK Phonska & $\mathrm{kg}$ & 3,47 & $3.400,00$ & $11.786,67$ & 144,44 & $491.111,11$ \\
\hline Pupuk SP36 & $\mathrm{kg}$ & 2,37 & $3.000,00$ & $7,100.00$ & 98,61 & $295.833,33$ \\
\hline Pupuk Kandang & $\mathrm{kg}$ & 80,67 & $1.000,00$ & $80.666,67$ & $3.361,11$ & $3.361 .111,11$ \\
\hline Obat-obatan & $\mathrm{gr} / \mathrm{BA}$ & 0,00 & & 0,00 & 0,00 & 0,00 \\
\hline TK Luar Keluarga & HOK & 0,00 & $70.000,00$ & 0,00 & 0,00 & 0,00 \\
\hline PBB & $\mathrm{Rp} / \mathrm{th}$ & 0,02 & $50.000,00$ & $1.183,33$ & 1,00 & $49.305,56$ \\
\hline Total Biaya Tunai & & & & $211.782,00$ & & $8.824 .250,00$ \\
\hline \multicolumn{7}{|l|}{ II. Biaya diperhitungkan } \\
\hline Sewa Lahan & $\mathrm{Rp} / \mathrm{th}$ & 0,02 & $4.000 .000,00$ & $94.666,67$ & 1,00 & $3.944 .444, .44$ \\
\hline TK dalam Keluarga & HOK & 7,55 & $70.000,00$ & $528.208,33$ & 314,00 & $22.008 .680,56$ \\
\hline Penyusutan Alat & $\mathrm{Rp}$ & & & $64.347,08$ & & $2.681 .128,47$ \\
\hline Total Biaya diperhitungkan & & & & $687.222,08$ & & $28.634 .253,47$ \\
\hline III. Total Biaya & & & & $1.374 .444,17$ & & $57.268 .506,94$ \\
\hline \multicolumn{7}{|l|}{ Pendapatan } \\
\hline I. Pendapatan Biaya Tunai & $\mathrm{Rp}$ & & & $2.546 .718,00$ & & $106.113 .250,00$ \\
\hline II. Pendapatan Biaya Total & $\mathrm{Rp}$ & & & 1.384 .055 .3 & & $57.668 .993, .06$ \\
\hline $\mathrm{R} / \mathrm{C}$ atas biaya tunai & & & & 13,03 & & 13,03 \\
\hline $\mathrm{R} / \mathrm{C}$ atas biaya total & & & & 2,01 & & 2,01 \\
\hline
\end{tabular}


Tabel 5. Persentase sumbangan pendapatan usahatai ubi kayu terhadap pendapatan rumah tangga responden petani ubi kayu di Kecamatan Seputih Banyak Kabupaten Lampung Tengah, 2018

\begin{tabular}{lrrrr}
\hline \multicolumn{1}{c}{ Keterangan } & $\begin{array}{c}\text { Ubi kayu pahit } \\
\text { (Rp/tahun) }\end{array}$ & $\begin{array}{c}\text { Persentase } \\
(\%)\end{array}$ & \multicolumn{1}{c}{$\begin{array}{c}\text { Ubi kayu manis } \\
(\text { Rp/tahun })\end{array}$} & \multicolumn{1}{c}{$\begin{array}{c}\text { Persentase } \\
(\%)\end{array}$} \\
\hline Pendapatan usahatani ubi kayu & $24.792 .275,42$ & 75,01 & $2.338 .893,00$ & 6,95 \\
Pendapatan usahatani non ubi kayu & $538.333,33$ & 1,63 & $21.500 .000,00$ & 63,91 \\
Pendapatan non usahatani & $7.720 .000,00$ & 23,36 & $9.800 .000,00$ & 29,13 \\
\hline Pendapatan rumah tangga & $33.050 .608,75$ & 100,00 & $33.638 .893,00$ & 100,00 \\
\hline
\end{tabular}

\section{Uji Beda Tingkat Pendapatan Usahatani Ubi Kayu Pahit dan Ubi Kayu Manis}

Pendapatan rata-rata usahatani ubi kayu pahit adalah Rp11.109.357,55/ha dan kayu manis adalah Rp57.668.993,06/ha. Artinya, pendapatan ratarata/ha ubi kayu manis jauh lebih besar dari pendapatan rata-rata/ha ubi kayu pahit. Perbedaan yang sangat besar tersebut disebabkan oleh harga output. Harga ubi kayu manis di tingkat petani $(\mathrm{Rp} 2.700 / \mathrm{kg}$ ) lebih besar dari harga ubi kayu pahit di tingkat petani (Rp1.266/kg). Dari Tabel 6 diketahui bahwa nilai t-hitung adalah 10.399, artinya terdapat perbedaan yang signifikan antara pendapatan usahatani ubi kayu pahit dan ubi kayu manis dengan taraf kepercayaan sebesar 99\%.

\section{KESIMPULAN}

Faktor-faktor yang mempengaruhi produksi ubi kayu pahit adalah jumlah pupuk NPK, pupuk urea, pupuk SP-36, dan umur panen, sedangkan faktorfaktor yang mempengaruhi produksi ubi kayu manis adalah luas lahan dan pupuk NPK. Pendapatan usahatani ubi kayu pahit menyumbang sebesar $75,01 \%$ dari total pendapatan rumah tangga petani ubi kayu pahit, tetapi pendapatan usahatani ubi kayu manis hanya menyumbang $6,95 \%$ dari total pendapatan rumah tangga petani ubi kayu manis di Kecamatan Seputih Banyak Kabupaten Lampung Tengah. Pendapatan usahatani ubi kayu manis lebih besar dibandingkan pendapatan ubi kayu pahit di Kecamatan Seputih Banyak Kabupaten Lampung Tengah.

Tabel 6. Hasil analisis uji t perbedaan pendapatan usahatani ubi kayu pahit dan ubi kayu manis di Kecamatan Seputih Banyak Kabupaten Lampung Tengah, 2018

\begin{tabular}{lcccc}
\hline \multirow{2}{*}{ Perlakuan } & \multicolumn{2}{c}{ Uji Lavene } & \multicolumn{2}{c}{ t-test } \\
\cline { 2 - 5 } & $\mathrm{F}$ & Sig & $\mathrm{t}$ & \multicolumn{2}{c}{ Sig (2-tailed) } \\
\hline Varians & & & & \\
sama & 32.126 & 0.000 & -13.854 & 0.000 \\
$\begin{array}{l}\text { Varians } \\
\text { tidak sama }\end{array}$ & & & \\
\hline
\end{tabular}

\section{DAFTAR PUSTAKA}

Ambarita MM, Prasmatiwi FE, dan Nugraha A. 2014. Analisis efisiensi produksi frontier dan pendapatan usahatani kedelai Sekolah Lapangan Pengelolaan Tanaman Terpadu (SL-PTT) di Kabupaten Lampung Selatan. JIIA, 2 (4): 348-355. http://jurnal.fp.unila. ac.id/index.php/JIA/article/download/989/895 [10 Februari 2018].

Arikunto S. 2006. Prosedur Penelitian Suatu Pendekatan Praktik. PT Rineka. Jakarta.

BPS [Badan Pusat Statistik] Lampung Tengah. 2017. Lampung Tengah dalam Angka (tahun 2016). BPS Lampung Tengah. Gunung Sugih. https://lampungtengahkab.bps.go.id/publicatio n/2017/08/11/8f9a8be50863f31fb9e172a2/kab upaten-lampung-tengah-dalam-angka-2017.ht ml. [10 Februari 2018].

BPTP [Balai Pengkajian Teknologi Pertanian] Lampung. 2008. Teknologi Budidaya Ubi Kayu. BPTP Lampung. Lampung. http://lampung.litbang.pertanian.go.id/ind/ind ex.php/berita/4-info-aktual/19-cara-tanamubikayu. [20 Juli 2018].

Koerniawati T. 2009. Maksimalisasi Profit dengan Satu Input dan Satu Output. Modul Ekonomi Produksi Pertanian: Pendekatan Neoklasik. III:116.http://tatiek.lecture.ub.ac.id/files/2009/ 07/debertin3.pdf. [16 Februari 2018].

Sekaran U. 2013. Research Methods for Business. John Wiley. West Sussex.

Sinabariba FM, Prasmatiwi FE, dan Situmorang S. 2014. Analisis efisiensi produksi dan pendapatan usahatani kacang tanah di Kecamatan Terbanggi Besar Kabupaten Lampung Tengah. JIIA, 2 (4) : 156-162. http://jurnal.fp.unila.ac.id/index.php/JIA/articl e/view/985. [10 Februari 2018].

Soekartawi. 2002. Analisis Usahatani. Universitas Indonesia Press. Jakarta.

2003. Teori EkonomiProduksi dengan Pokok Bahasan Analisis Fungsi CobbDouglas; Edisi Ketiga. CV Rajawali. Jakarta. 
Sumodiningrat G dan Iswara. 1993. Ekonomi Produksi. Karunika. Universitas Terbuka. Jakarta.

Supriyatno, Pujiharto, dan Budiningsih S. 2018. Analisis efisiensi alokatif penggunaan faktorfaktor produksi usahatani ubi kayu di Desa Punggelan Kecamatan Punggelan Kabupaten Banjar Negara. Jurnal Agritech, 10 (1): 30-40. https://www.neliti.com/id/publi cations/42129 /analisis-efisiensi-alokatif-penggunaan-faktorproduksi-usahatani-ubikayu-manihot. $\quad[12$ Januari 2019].

UPTD [Unit Pelaksana Teknis Daerah] Pertanian Kecamatan Seputih Banyak. 2017. Sebaran Luas Lahan Pertanian Kecamatan Seputih Banyak Tahun 2017. UPTD Seputih Banyak. Lampung Tengah. 